Proceedings

\title{
Unexpected Migration of Benzoyl Group in the Synthesis of 3-Benzoyl-2-Phenylbenzofurans under Wittig Conditions ${ }^{+}$
}

\author{
Giovanna Lucia Delogu* and Michela Begala \\ Dipartimento di Scienze della Vita e dell' Ambiente, Università degli Studi di Cagliari, 09124 Cagliari, Italy; \\ michelabegala@unica.it \\ * Correspondence: delogug@unica.it; Tel.: +39-070-675-8566 \\ + Presented at the 22nd International Electronic Conference on Synthetic Organic Chemistry, 15 November- \\ 15 December 2018; Available Online: https://sciforum.net/conference/ecsoc-22.
}

Published: 14 November 2018

\begin{abstract}
In the present work, we report the unexpected formation of isomeric 3-benzoyl-2phenylbenzo[b]furans using triphenylphosphonium salt and benzoyl chlorides under Wittig conditions. In particular, we found that the o-[(benzoyloxy)benzyl]-triphenyl-phosphoranes constitute the key intermediate that reasonably undergoes benzoyl group migration.
\end{abstract}

Keywords: Wittig reaction; 3-aroyl-2-phenylbenzofurans; phosphorane

\section{Introduction}

3-Aroyl[b]benzofurans represent the structural cores of a large number of bioactive molecules in current pharmaceutical use or development. As a result, numerous approaches towards the synthesis of 3-acylbenzofurans have been disclosed in the literature.

The Wittig reaction is an easy procedure for the benzofuran ring system. In a previous paper, Hercouet and Le Corre reported that the intramolecular condensation of $o$-acyloxybenzylidenetriph enylphosphoranes II leads to benzofuran in aprotic medium (toluene) or acylated product in protic medium (t-BuOH) [1,2].

We recently found that the reaction of the triphenylphosphonium salt and aroyl chlorides in toluene leads together with the expected 2-phenylbenzofurans 3 also to 3-benzoyl-2-phenylbenzo[b] furans 4 via ylide acylation under Wittig conditions (Scheme 1) [3].<smiles>Oc1ccccc1C[Pb]Br</smiles>

1<smiles>[R][R]1ccccc1C(=O)Cl</smiles>

2

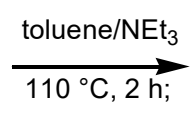<smiles>[R]c1cccc(-c2cc3ccccc3o2)c1</smiles>

3<smiles>[R]c1ccc(C(=O)c2c(-c3ccccc3)oc3ccccc23)cc1</smiles>

4

Scheme 1. Synthetic route towards 2-phenylbenzofurans 3 and 3-benzoyl-2-phenylbenzofurans 4.

We proved that the key intermediate that leads to the 3-benzoyl derivatives was the o[(benzoyloxy)benzyl]-triphenyl-phosphoranes II (Scheme 2). 


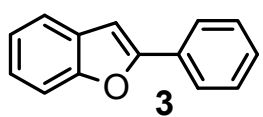

Route $\mathrm{A} \uparrow-\mathrm{Ph}_{3} \mathrm{PO}$<smiles>O=C(Oc1ccccc1C[PH3+])c1ccccc1</smiles>

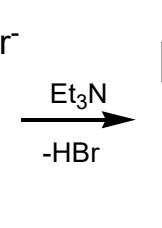<smiles>O=C(Oc1ccccc1C(=O)[PH2+][PH3+])c1ccccc1</smiles><smiles>O=C(Cl)c1ccccc1</smiles><smiles>O=C(c1ccccc1)c1oc2ccccc2c1-c1ccccc1</smiles>

Scheme 2. Proposed reaction mechanism.

However, the reaction of the phosphorane II with substituted benzoyl chloride, unexpectedly showed the formation of two sets of 3-acyl isomers (Route B). These data prompted us to investigate the Wittig reaction.

\section{Results and Discussion}

O-[(benzoyloxy)benzyl]-triphenyl-phosphoranes II was reacted with benzoyl chlorides substituted with electron withdrawing and donating groups.

$O$-[(benzoyloxy)benzyl]-triphenyl-phosphoranes II was prepared starting from ortho cresol [4,5]. Subsequently, II was reacted with 4-nitrobenzoyl chloride in the presence of triethylamine in toluene. The reaction mixture showed the formation of two 3-acyl isomers (Scheme 3), i.e., the 3-benzoyl-2(4'-nitrophenyl)benzofuran $4 \mathbf{a}$ and 3-(4'-nitrobenzoyl)-2-phenylbenzofuran $\mathbf{4 b}$, as identified by GC/MS analysis.
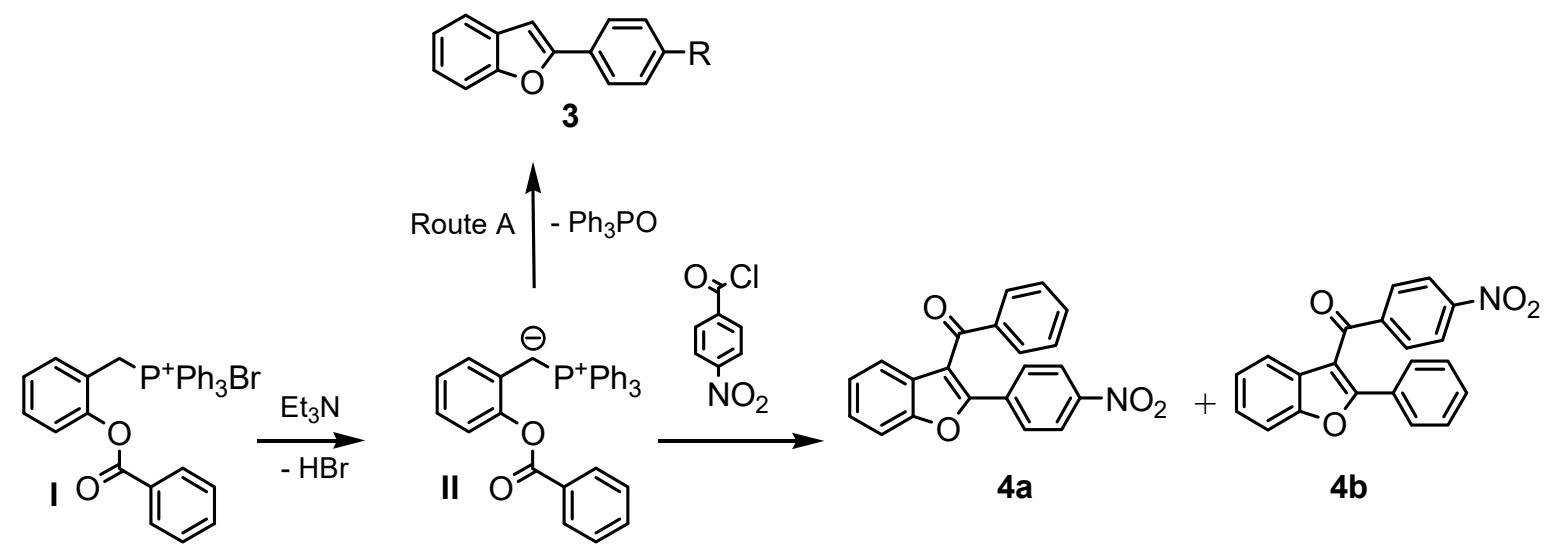

Scheme 3. Preparation of compounds $4 \mathbf{a}$ and $\mathbf{4 b}$ from intermediate II.

The same behaviour was also observed when 4-methoxybenzoyl chloride was used. These results clearly suggest that the regioselective benzoyl group migration occurred to some extent.

\section{Conclusions}

Our preliminary results demonstrated that, under aprotic conditions, also 3-acyl derivative can be obtained from phosphoranes and that the intramolecular migration of the benzoyl group occurred. This finding is of considerable interest as it allows to prepare a wide variety of 3-acylbenzofuran derivatives difficult to obtain with alternative synthetic methods. 


\section{Materials and Methods}

Starting materials, solvent and reagents were obtained from commercial suppliers (SigmaAldrich) and were used without further purification. All reactions were performed under $\mathrm{N}_{2}$ atmosphere. Analytical thin layer chromatography (TLC) was carried out on silica gel 60 F254 plates $(0.25 \mathrm{~mm})$, visualized by exposure to UV light. Column chromatography purifications were performed using Aldrich silica gel (60-120) mesh size. Melting points were determined on a Stuart Scientific SMP 11 melting point apparatus and are uncorrected. Concentration and evaporation of the solvent after reaction or extraction were carried out on a rotary evaporator (Büchi Rotavapor) operating at reduced pressure. GC-MS: low resolution mass spectrometric experiments were carried out on a Saturn 2000 ion-trap coupled with a Varian 3800 gas chromatograph (Varian, Walnut Creek, CA) operating under EI conditions (electron energy $70 \mathrm{eV}$ ). A CIP Sil-8 CB Lowbleed/MS capillary column ( $30 \mathrm{~m}, 0.25 \mathrm{~mm}$ i.d., $0.25 \mathrm{~mm}$ film thickness) was used. The oven temperature was programmed from $50{ }^{\circ} \mathrm{C}$ (held for $2 \mathrm{~min}$ ) to $210{ }^{\circ} \mathrm{C}$ at $20^{\circ} \mathrm{C} / \mathrm{min}$ (held for $15 \mathrm{~min}$ ). The temperature was then ramped to 350 at $20^{\circ} \mathrm{C} / \mathrm{min}$. The transfer line was maintained at $250^{\circ} \mathrm{C}$ and the injector port (30:1 split) at $280^{\circ} \mathrm{C}$

General procedure for the preparation of 2-methylphenylbenzoate [4,5]: ortho-cresol $(1 \mathrm{~g}, 0.92 \mathrm{mmol})$ was taken in pyridine $(10 \mathrm{~mL})$ and to it benzoyl chloride $(1.2 \mathrm{~g}, 0.92 \mathrm{mmol})$ was added drop-wisely at 0 ${ }^{\circ} \mathrm{C}$ with stirring and kept overnight. The reaction mixture was warmed on a water bath for $10 \mathrm{~min}$ and decomposed with ice cold hydrochloric acid (1:1), followed by extraction with ether $(3 \times 15 \mathrm{~mL})$, washed with brine $(3 \times 10 \mathrm{~mL})$, and dried over anhydrous sodium sulphate. Yield: $95 \%$.

General procedure for the preparation of 2-bromomethylphenylbenzoate [4,5]: 2-methylphenyl benzoate (1.5 $\mathrm{g}, 7 \mathrm{mmol})$ and $\mathrm{N}$-bromosuccinimide (NBS) $(1.28 \mathrm{~g}, 7.2 \mathrm{mmol})$ were taken in dry $\mathrm{CCl}_{4}(15 \mathrm{~mL})$. The mixture was heated to $85{ }^{\circ} \mathrm{C}$ before azobisisobutyronitrile (AIBN) was added in few crystals (ca. 3 $\mathrm{mg}$ ). After heating at reflux for $1 \mathrm{~h}$, more AIBN was added. The flask was kept at reflux for $5 \mathrm{~h}$. The reaction mixture was cooled down to room temperature and precipitated succinimide was filtered off. The solvent was removed in vacuo and the residue was chromatographed on silica gel (Hexane/EtOAc 2:1) to give 2-bromomethylphenylbenzoate as colorless crystals. Yield: $75 \% ; \mathrm{mp} 79^{\circ} \mathrm{C}$.

General procedure for the preparation of 2-benzyloxy-benzyl triphenyl phosphomium bromide I [1,2]: A mixture of 2-bromomethylphenylbenzoate $(5.1 \mathrm{mmol})$ and $\mathrm{PPh} 3 \cdot \mathrm{HBr}(5.1 \mathrm{mmol})$ in toluene $(60 \mathrm{~mL})$ was stirred under reflux for $4 \mathrm{~h}$. The solid formed was filtered and washed with toluene to give the desired compounds. White solid; yield: $60 \%$.

General procedure for the preparation of 2-phenylbenzofuran 3 and 3-(4'-Nitrobenzoyl)-2-phenylbenzofuran $4 a$ and 3-benzoyl-2-(4'-nitrophenyl)benzofuran 4b: A mixture of 2-benzyloxy-benzyl triphenyl phosphomium bromide $\mathbf{I}(0.6 \mathrm{mmol})$ and 4-nitrobenzoyl chloride $(1.5 \mathrm{mmol})$ in a mixed solvent (toluene $15 \mathrm{~mL}$ and $\mathrm{Et}_{3} \mathrm{~N} 0.4 \mathrm{~mL}$ ) was stirred under reflux for $2 \mathrm{~h}$. The precipitate was removed by filtration. The filtrate was concentrated, and the mixture containing the three reaction products, $3,4 a$, and $\mathbf{4 b}$ were analyzed by GC/MS.

2-(4'-Nitrophenyl)benzofuran 3: MS (EI, 70eV): m/z (\%): 239 (100) [M+], 209 (37), 165 (26).

3-Benzoyl-2-(4'-nitrophenyl)benzofuran 4a: MS (EI, $70 \mathrm{eV}): \mathrm{m} / \mathrm{z}(\%): 343(100)\left[\mathrm{M}^{+}\right], 221$ (70).

3-(4'-Nitrobenzoyl)-2-phenylbenzofuran 4b: MS (EI, 70 eV): m/z (\%): 343 (100) [M+], 266 (65).

\section{References}

1. Hercouet, A.; Le Corre, M. Une nouvelle voie d'accès aux benzofurannes. Tetrahedron Lett. 1979, 23, 21452148, doi:10.1016/S0040-4039(01)86285-7.

2. Hercouet, A.; Le Corre, M. Acyloxyalkylidènephosphoranes-III: Etude des $\omega$-acyloxybenzylidènetriphén ylphosphoranes.nouvelle voie d'accès aux benzofurannes. Tetrahedron 1981, 37, 2867-2873, doi:10.1016/S0040-4020(01)92357-9 
3. Begala, M.; Caboni, P.; Matos, M.J.; Delogu, G.L. Unexpected one-step synthesis of 3-benzoyl-2phenylbenzofuransunder Wittig conditions. Tetrahedron Lett. 2018, 59, 1711-1714, doi:10.1016/j.tetlet.2018.03.048.

4. Ghosh, S.; Das, J. A novel photochemical Wittig reaction for the synthesis of 2-aryl/alkylbenzofurans. Tetrahedron Lett. 2011, 52, 1112-1116, doi:10.1016/j.tetlet.2010.12.104

5. Routasalo, T.; Helaja, J.; Kavakka, J.; Koskinen, A.M.P. Development of Bis(2-picolyl)amine-Zinc Chelates for Imidazole Receptors. Eur. J. Org. Chem. 2008, 18, 3190-3199, doi:10.1002/ejoc.200700926

(C) 2018 by the authors. Licensee MDPI, Basel, Switzerland. This article is an open access article distributed under the terms and conditions of the Creative Commons Attribution (CC BY) license (http://creativecommons.org/licenses/by/4.0/). 